\title{
Health on a Cloud: Modeling Digital Flows in an E-health Ecosystem
}

\author{
Felix Lena Stephanie and Ravi S. Sharma
}

\author{
School of Communication \& Information, Nanyang Technological University, Republic of Singapore
}

\begin{abstract}
A unified and well-knit e-health network is one that provides a common platform to its key stakeholders to facilitate a sharing of information with a view to promoting cooperation and maximizing benefits. A promising candidate worthy of being considered for this ponderous job is the emerging 'cloud technology' with its offer of computing as a utility, which seems well-suited to foster such a network bringing together diverse players who would otherwise remain fragmented and be unable to reap benefits that accrue from cooperation. The e-health network serves to provide added value to its various stakeholders through syndication, aggregation and distribution of this health information, thereby reducing costs and improving efficiencies. Because such a network is in fact an interconnected 'network of networks' that delivers a product or service through both competition and cooperation, it can be thought of as a business ecosystem. . This study attempts to model the digital information flows in an e-health ecosystem and analyze the resulting strategic implications for the key players for whom the rules of the game are bound to change given their interdependent addedvalues. The ADVISOR framework is deployed to examine the values created and captured in the ecosystem. Based on this analysis, some critical questions that must be addressed as necessary preconditions for an e-Health Cloud, are derived. The paper concludes with the conjecture that "collaboration for value" will replace "competition for revenue" as the new axiom in the health care business that could ideally usher in a fair, efficient and sustainable ecosystem.
\end{abstract}

Keywords: Cloud computing, electronic health, electronic medical records, value networks, patient-centric health.

\section{INTRODUCTION}

\subsection{Background}

It is no exaggeration to say that "e-revolution" has radically transformed the conventional landscape of business and consumerism, as evident from the variety of e-initiatives successfully launched over the last couple of decades. Today, the Internet has become entwined with most aspects of day-to-day living, facilitating communication, entertainment, education, banking and a host of e-commerce transactions online. Often such disparate services and applications have shared what is now known as a cloud computing infrastructure [1, 2]. Etymologically, the term "cloud computing" comes from 'The Cloud' (internet-based computers) which can provide a variety of services [3]. Simply defined, cloud computing is a range of IT services delivered over the Internet - Software as a service (SaaS), Platform as a service (PaaS) and Infrastructure as a service (laaS) [4, 5]. However, despite the Internet having revolutionized most aspects of human life, its foray into healthcare has been relatively inconsequential possibly on account of the complexities inherent in the industry [6-9]. Although the arrival of e-health may have been recent, its long-term potential is so immense [10-13]. A case in point is the dramatic rise in the US population looking for health information online, which jumped from 10 million in

*Address correspondence to this author at the School of Communication \& Information, Nanyang Technological University, Republic of Singapore; Tel: +65 67904414; E-mail: rsharma@pmail.ntu.edu.sg
2000 to 100 million in early $2007^{1}$. It was also estimated that by 2013 about $45 \%$ of US adults with a chronic condition would be using the internet to manage their condition. This trend, needless to say, is increasingly getting conspicuous all over the world including developing countries. All this, is a standing testimony to healthcare consumers' "unquenchable need for more and greater access to health information and services" [14, pp.2].

Coupled with these developments is the policy imperative of many governments to reform healthcare by making substantial investments in health information technology (HIT) to improve the safety, quality and value of healthcare $[8,15]$. Such trends are gaining traction globally, as evidenced by the plethora of ehealth projects that have stemmed worldwide in recent years ${ }^{2}$. According to MarketsandMarkets $(2015)^{3}$, the world healthcare IT market is expected to grow to $\$ 228.7$ billion in 2020 at a CAGR of $13.4 \%$ during the forecast period of 2015 to 2020 .

Ideally, e-health should encompass medical informatics, public health and business, as well as include within its purview health services and information that are delivered and enhanced through the Internet and related technologies [16]. An

\footnotetext{
'Manhattan Research LLC Survey, 2007

${ }^{2}$ https://www.moh.gov.sg/content/dam/moh_web/Publications/Information\%20P apers/2014/NEHR/English\%20Brochure\%20(Final).jpg; http://www.computerweekly.com/news/2240215175/UK-shows-biggest-takeup-of-electronic-Health-records-in-Europe; Arizona telemedicine network, USA ${ }^{3}$ http://www.marketsandmarkets.com/Market-Reports/healthcare-it-252.html
} 
integration of tele-health technologies with the Internet, e-health has also the potential to enhance the quality and value of health services delivery through improved efficiencies and diminished costs thereby developing new markets $[14,17]$. In essence, e-health comes with the promise of improved quality of care, greater safety, reduced costs, reduced medical errors, increased efficiency of information flow and most importantly, empowerment of healthcare consumers in their healthcare decisions [12, 18-20].

Notwithstanding the unlimited potential of e-health to transform the healthcare industry, there are several barriers to its adoption, one of them being a misalignment of incentives between investors in ehealth and its direct beneficiaries [7, pp. 266, 21]. Electronic Health Records (EHRs), which are longitudinal repositories of patient health information, are a key component of the healthcare system [22-24]. Historically, the responsibility of implementing EHRs was inexorably with healthcare providers who found the investment daunting more so because they perceived their own benefits from the implementation scant as compared to benefits that accrued to other beneficiaries such as the insurers and technology vendors $[25,26]$. It has been suggested that cloud computing, may be a boon to healthcare providers, making it compelling for them to acquire technology as a cloud-based service rather than struggle with the huge IT investments associated with quality patient care [27]. With e-health becoming a national level agenda in several countries, digitized clinical data is expected to grow exponentially, and cloud computing could just be the technology needed at the moment. Most significantly, it could put healthcare providers at ease by significantly reducing their EHR investment costs, which has been a major deterrent to e-health adoption and use. However, this is not to say that technological advancements like cloud technology will remove or even minimize the barriers confronting the healthcare providers with the advent and diffusion of ehealth. A game theoretic view of some of these major barriers to e-health follows.

\subsection{Barriers to E-Health: A Game Theoretic View}

Game theory is a set of analytical tools that helps comprehend the dynamics that unfold when decisionmakers interact [28]. It is the study of conflict and cooperation among intelligent, rational entities often referred to as 'players', in their decision-making processes [29]. A game theoretic view of the major barriers to e-health particularly from the healthcare providers' perspective makes it evident that these are manifestations of the prisoner's dilemma, a classic example to demonstrate game theory. Luce and Raiffa [30] in their book, Games and Decisions, describe Prisoner's Dilemma as follows:

Two suspects are taken into custody and separated. The district attorney is certain they are guilty of a specific crime, but he does not have adequate evidence to convict them at trial. He points out to each prisoner that each has two alternatives: to confess to the crime the police are sure they have done, or not to confess. If they both do not confess, then the district attorney states he will book them on some very minor trumped-up charge such as petty larceny and illegal possession of a weapon, and they will both receive a minor punishment; if they both confess they will be prosecuted, but he will recommend less than the most severe sentence; however, if one confesses and the other does not, then the confessor will receive lenient treatment for turning state's evidence whereas the latter will get "the book" slapped at him. (p. 95)

Prisoner's dilemma, in other words, is the conflict between self-interest and group interest. Rapoport and Chammah [31] define prisoner's dilemma as a mixture of interpersonal and intrapersonal conflict, which eventually leads to individual defections culminating in an overall scenario of less desirable outcomes [32]. In the context of e-health, these are some typical dilemmas faced by healthcare providers during the various stages of the evolution of e-health and may be considered to fall into two categories namely (i) participation dilemmas and (ii) cooperation dilemmas. These dilemmas, if unresolved, may render e-health unfeasible and unsustainable. A brief account of each of the dilemmas is given below.

\subsubsection{Participation Dilemmas}

These are barriers that deter healthcare providers from taking the essential first steps towards e-health, which involves making substantial investments in building Electronic Health Records (EHRs). What follows is a short discussion of these dilemmas:

\subsubsection{Productivity Paradox}

The famous quip by Robert Solow, Nobel Laureate in Economics, that, "we see computers everywhere 
except in the productivity statistics" (New York Times Book Review, 1987), still rings true after decades, especially in the context of investments in e-health. Some healthcare organizations, for instance, still challenge the much advocated link between investments in technology and improved organizational performance, keeping alive the debate on IT payoff, referred to in literature as the "productivity paradox" $[33,34]$.

In the absence of demonstrable evidence of positive payoffs from e-health investments [35], the strategy most prevalent among individual healthcare providers is defection to e-health rather than joint cooperation. This would mean that if healthcare providers are not motivated to invest in EHRs due to the productivity paradox, e-health may continue to remain a distant dream.

\subsubsection{Tragedy of the Digital Commons}

Electronic Health Records (EHRs) are the building blocks of e-health that need to be heavily invested in and created by the healthcare providers. These digital health records also need to be enabled for exchange and reuse of health data by other players in the network such as patients, payers, vendors, and other healthcare providers [36], so that the benefits of ehealth are harnessed in toto. In other words, in a patient-centric e-health network, health data is viewed and treated as a public good or "commons" so that every stakeholder including patients can consume the resource (i.e. the health data) without necessarily contributing to it. Albanese and Van Fleet [37] describe this as 'free-riding' where a member of a group benefits from its access to a common resource more than it actually contributes to the cost of this common resource. This 'free-riding' is reminiscent of the misaligned incentives discussed in the context of ehealth and often deters healthcare providers from investing in e-health which in turn might prove detrimental to other players. If healthcare providers shirk from investing in e-health, it will only lead to a deficient or less desirable outcome for everyone, resulting in a situation referred to by Adar and Huberman [38] as the 'tragedy of the digital commons'.

\subsubsection{Cooperation Dilemmas}

These dilemmas, as different from participation dilemmas, relate to such healthcare providers who have already invested in EHRs for productivity gains, but are reluctant to share the EHRs with other players in the network. Two such dilemmas are:

\subsubsection{Information Asymmetry}

It is said that the physician-patient relationship is often characterized by asymmetric information [39, 40]. This is because a physician who examines a patient acquires information about the patient which the latter cannot access on his own [40]. Such information asymmetry results in provider-centrism where the providers are very much in control of their patients' healthcare decisions and choices, which may not always be in the patients' interest.

However, given the potential of e-health to foster sharing and exchange of health data, it is suggested from time to time that information asymmetries of this kind may be reduced to facilitate greater patient empowerment.

Health data of individual patients, though maintained by healthcare providers in heavily invested systems, may be viewed as a common property resource owned by and accessible to both healthcare providers and patients. However, the reality is that such health data may be under-utilized, if not totally unutilized, especially by patients for reasons beyond their control. One basic reason is that, healthcare providers who have invested in EHRs, are unwilling to progress to the next level by sharing the data with their patients and other players in the network. If such information sharing is made possible as in an efficient market system, patients would really be empowered to shop around and choose a healthcare provider on their own, based on criteria such as cost-effectiveness, reliability and quality [7]. This would go a long way in jeopardizing provider-centrism, as well as, providers' return on EHR investments.

\subsubsection{Closed Networks}

Some healthcare providers may be willing to invest in EHRs if they perceive certain significant productivity gains from the investment, and furthermore, take ehealth to the next level by sharing their patients' health data with parties outside their institutional walls. However, they may only do so using proprietary platforms which invariably limit such sharing to a closed network of a select group of partners. This may endanger the interoperability, and hence, the exchangeability and reusability of health data beyond the network. Such an outcome defeats the very purpose of e-health namely patient-centrism where patients have unlimited and ubiquitous access to their health data. In closed e-health networks, patients' choices may be limited to a few partners or players 
carefully selected by the healthcare provider in extreme self-interest.

In view of the aforementioned dilemmas, it would be a worthwhile venture to investigate the sustainability of a patient-centric e-health ecosystem with particular focus on the dilemmas of the healthcare providers without whose participation and cooperation patientcentric e-health may not be possible.

Against this backdrop, this paper undertakes to examine two key research questions:

Research Question 1: Who are the key players in the e-health ecosystem?

Research Question 2: What are the potential values they create and capture through digital information flows?

The objective of these RQs is to adequately model the e-health ecosystem in terms of the key players, their roles, and the potential major digital flows among them. Such modeling is a prerequisite to the identification of values generated (created and captured) in the e-health ecosystem for subsequent analysis. Value is "created" when a firm (player) develops its core competencies, capabilities and advantages to perform work activities that differentiate it from competitors, and "captured" when the firm derives economic returns in relation to the value it creates [41]. It will be of particular interest to observe the value flows involving the healthcare providers who are fraught with dilemmas of participation and cooperation in e-health.

The remainder of the paper is organized as follows. The next section reviews the e-health ecosystem and the roles of players and their business models. Section 3 describes a conceptual framework for modeling ehealth digital flows that was derived from the scholarly literature in consultation with a panel of expert level practitioners. Section 4 uses the ADVISOR framework to compare the values created and values captured by players in the ecosystem. Based on the analysis, we conclude the paper with a research agenda in section 5.

\section{METHODS}

Despite recent scholarly interest in e-health $[15,19$, $23,42-46]$, the key players, the opportunities that accrue to them and the commitments required of them have not been adequately modeled and analyzed. This section describes a conceptual model for digital information flows in the e-health ecosystem and an analytic framework for the resulting strategic implications for the key players for whom the rules of the game are bound to change given their interdependent fortunes. As a first step, a preliminary model of the e-health ecosystem was developed primarily based on literature and industry observations. This process led to the identification of the six key ehealth players, and the subsequent modeling of the potentially major digital flows among them. Based on an analysis of these digital flows using the ADVISOR framework adopted by [47] for the digital market space, the values-created and values-captured by the key players in the e-health ecosystem were identified in a systematic manner [48]. These preliminary models were later validated through interviews with industry experts for the purpose of calibration of the models based on feedback gathered from them. More specifically, these were professionals from different walks of the healthcare industry like the ministry of health, IT department of healthcare providers, health IT vendors, BPOs in the healthcare industry etc. from China, India, Singapore and the United States, where public and private e-health initiatives are at various stages of progress. Such validation was considered necessary to steer the research to focus on the key players in e-health and the really critical issues facing them in their participation in the cloud network. The expert interview template may be found in the appendix.

\subsection{The E-Health Ecosystem}

An e-health ecosystem should facilitate easy access to information for all stakeholders involved in the ehealthcare processes $[14,20,49,50]$. It needs to be kept in mind that what determines the potential of an ehealth market system is evidence-based medicine which is defined as "the conscientious, explicit and judicious use of current best evidence in making decisions about the care of individual patients" [51, pp.71] --intuitive in its appeal for doing better with scarce resources. In such a context, health data assumes great significance inasmuch as it can foster evidence-based patient-centric medicine that is efficient, and offers high quality and value $[46,52]$. To create a patient-centric health network that is seamlessly connected for exchange and reuse of health data, an e-health system must harness the combined power of technology and the Internet. EHRs form the building blocks $[22,53]$ of such a network but their diffusion has been rather slow, one significant 
reason being resistance from healthcare providers who are expected to implement these expensive systems in the face of uncertain ROI [54, 55]. Therefore, until recently, the digitization of healthcare has primarily focused on creating electronic health records (EHRs) for patients, rather than on total digital health systems (TDHS) which simultaneously offer intra- and interenterprise benefits because of their scalability, interoperability and distributable capabilities [23, 56, 57]. Cloud computing technologies come with the promise of a strong foundation to support such an integrated health system or TDHS by providing infrastructure and services on a shared basis at affordable costs $[5,58]$.

E-health is a broad term that covers various activities related to the use of technology and the Internet to deliver healthcare [6], and there does not seem to be any universal consensus on its scope [59]. In this paper however, we define e-health as a TDHS that encompasses all the key players and allows for interoperability among them by providing a common platform for interfaces and transactions among them. Yet another key element of patient-centricity which a TDHS should incorporate is the PHR (Personal Health Record) which gives an individual access to their "lifelong health story" [60] and thus augments the value of e-health resources. Essentially, the PHR is an electronic record containing health-related information managed, shared, and controlled by an individual [61]. Like the EHR, the PHR also conforms to nationally recognized interoperability standards and contains information drawn from multiple sources. It is widely believed that cloud computing in healthcare (health cloud) has the potential to foster such a patient-centric TDHS.

In order to ascertain who the key players in the ehealth ecosystem are, we reviewed e-health related literature that has emerged over the past decade and a half, and also observed current market trends. According to Busch [62], the healthcare market has players at two levels - primary and secondary. At the primary level of the healthcare continuum are market players who use health information to provide patient care directly or indirectly (by supporting direct providers of patient care). Secondary market players on the other hand, use health information in roles other than direct and indirect patient care activities. The above definition served as a useful criterion for this research to distinguish the primary from the secondary level ehealth market players. Four key stakeholders (players) namely Patients, Providers, Payers and Vendors were discernible from the work of several authors [14, [6368]. A potential fifth player namely the infomediary was also observed in the systems they described, although such a player was not explicitly mentioned by these authors. While examples of such infomediaries abound in other industries, they have only relatively recently begun to emerge in e-health, and are predicted to rise to prominence aided and abetted by cloud technology. Zahedi and Song [69] describe a health infomediary as a neutral online entity that could offer a range of services - illness and wellness related information, advice, guidance, assessment and referrals. With five key players already identified, a deeper review of literature was further undertaken to spot any other potential key players in the e-health ecosystem. Such probing revealed that it was not until 2003 that Regulators began to be acknowledged as part of the ecosystem, when Broderick \& Smaltz [70] and later Walker et al. [18] recognized the role of the government as not just one of the payer sources, but also that of the regulator of the e-health market space. It is imperative for an e-health system to comply with standards and policy regulations specified by these regulators thus making it evident that the role of the Regulator as a primary level e-health market player cannot be overlooked. This is a reasonable outcome as health is a universal public good.

\subsection{Key Players and Roles}

The first step was to identify the key players in the e-health ecosystem. As mentioned earlier, a comprehensive view of the players and their roles was synthesized from literature and validated in the field. This is summarised in Table 1.

Thus six key players are identified at the primary level: Patients (Consumers), Providers, Payers, Vendors, Infomediaries and Regulators. At the secondary level are several public and private organizations focusing on public health, patient autonomy and clinical case management activities (Busch, 2008). The e-health ecosystem as we describe it in this study is shown in Figure 1.

With healthcare providers looking at automating processes at lower costs with higher gains, cloud computing may just be the right technology to embrace in healthcare IT. The technology provides access to data and applications which are stored in replicated storage servers and accessible via any Internet connection subject to authentication, authorization and access checks. Furthermore, it has the potential to 
Table 1: Key E-Health Players and Roles

\begin{tabular}{|c|c|}
\hline Players & Role \\
\hline $\begin{array}{l}\text { Patients / } \\
\text { Healthcare } \\
\text { Consumers }\end{array}$ & Recipients of wellness- or illness-related health services for personal or next-of-kin's consumption [14, $62-65,70]$. \\
\hline Providers & $\begin{array}{l}\text { State-authorized providers of health services - clinical settings and professional staff that design, implement, and/or } \\
\text { execute healthcare initiatives as part of wellness or illness programs }[14,62-65,70] .\end{array}$ \\
\hline $\begin{array}{l}\text { Third-Party } \\
\text { Vendors }\end{array}$ & $\begin{array}{l}\text { Diverse market players who play a supporting role to the Providers in their provision of healthcare. These players } \\
\text { include health IT vendors, medical equipment vendors, pharmaceutical vendors, transportation services, laboratories, } \\
\text { legal systems, billing agents etc. }[14,62,65,70] .\end{array}$ \\
\hline Payers & $\begin{array}{l}\text { Any entity that processes the claims payment transactions of healthcare episodes on behalf of plan sponsors. A plan } \\
\text { sponsor is an entity that funds a health program - private insurance plans, government-sponsored plans, employer- } \\
\text { sponsored plans etc. }[14,62,70] .\end{array}$ \\
\hline Infomediaries & $\begin{array}{c}\text { Organizations that act as mediators or brokers to facilitate information exchange among its network participants, gather } \\
\text { pertinent health information from various sources, and syndicate, aggregate and distribute it to foster patient-centric } \\
\text { health care }[62,71,72] \text {. }\end{array}$ \\
\hline Regulators & $\begin{array}{l}\text { Public and private organizations that develop capabilities for standards-based, secure and confidential exchange of } \\
\text { health information to improve the coordination of care among the e-health market players }[18,70,73] \text {. }\end{array}$ \\
\hline
\end{tabular}

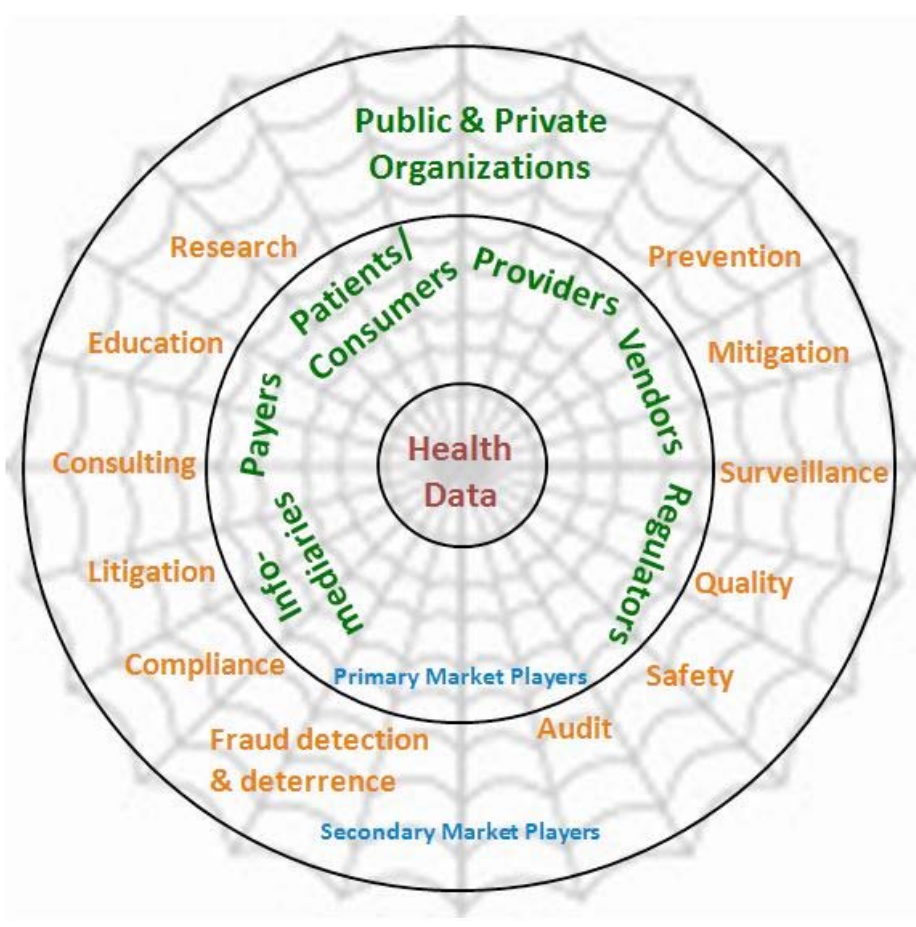

Figure 1: The e-health ecosystem.

reduce the IT infrastructure costs of healthcare organizations by three to five times [27], and to eliminate the IT maintenance costs that are major roadblocks to EHR adoption [74]. Besides these benefits, cloud computing offers an infinite and elastic structure which can drive profitability for healthcare providers by improving resources utilization and increasing their scalability [75].

As the healthcare industry looks beyond EHRs for meaningful use of health data, the cloud computing model is expected to play a significant role in health information exchanges [76], which refer to the electronic movement of health-related information among organizations according to nationally recognized standards. With such 'health clouds' already gaining traction in some countries, cloud providers now have the opportunity to function as infomediaries who can create new values in the ehealth ecosystem beyond exchange efficiencies, by reducing information asymmetries among the market players, thereby increasing market transparency and 
efficiency [77-79]. A case in point is Singapore's $\mathrm{H}$ Cloud $^{4}$ (Consolidated Healthcare Cloud) which is believed to lower the country's public health expenditure.

\section{ANALYTIC FRAMEWORK}

The ADVISOR Business Model was utilized to analyze the e-health market space in order to derive the potential values created and captured by its players. The ADVISOR framework is an extension of the VISOR Business Model which was first formulated by El Sawy et al. [80] at the Centre for Technology \& Management of the Marshall School of Business. The extended ADVISOR framework was developed at the Special Interest Group on Interactive Digital Enterprise (SIGIDE) specifically for digital marketplaces [47]. This framework helps articulate how the various players in the networked digital industry may deliver value to their network members through both cooperative and competitive means (sometimes at the same time resulting in what is referred to as 'co-opetition'5).

ADVISOR adds two components to VISOR Adoption by Consumers and Disruptive Innovation - and also comprises the following five components: Value, Interface, Service Platform, Organizing Model and Revenue/Cost Sharing. More specifically, the ADVISOR model suggests that the value created and captured by a player in the digital marketplace is a function of the following key design parameters:

- Value Proposition for the Customer Compelling value of the digital product or service provided by a player.

- Interface or the "Wow" Interface Experience Easy to use, simple and convenient user interface for the successful delivery of the product or service.

- Service Platforms to Enable Delivery Platform(s) that support the business processes and relationships needed to deliver the product or service.

- Organizing Model for Processes and Relationships - Value chains, business processes and partner relationships to ensure

\footnotetext{
${ }^{4}$ https://www.ihis.com.sg/MediaCentre/NewsArticles/Pages/Private-Cloud-ToCut-Costs-For-Singapore's-Public-Health.aspx

${ }^{5}$ Term coined by Brandenburger \& Nalebuff (2005)
}

the effective and efficient delivery of the product or service.

- Revenue / Cost Sharing for Partners Business justification for the investments in providing the product or service and a fair return of revenues for all players involved.

* Adoption by Customers - How customers in effect co-create additional value by using or consuming the product or service.

* Disruptive Innovation - Impact of new technologies and business arrangements on the market.

We postulate that the total value of an e-health ecosystem is a function of the above components [48]. We note that these "values" are not inconsistent with the terms "added value" and "value added" introduced by Brandenburger \& Stuart [81]. While the former may be defined as the difference between the value derived by players from transacting through the platform and the value available from the players' next-best alternative [82], the latter is described by Rappaport [83] as the ability of a player to create value in excess of the cost of producing it [81].

A comparison of the potential values created (added value) and captured (value added) in the e-health ecosystem will help determine if "collaboration for value" will pave the way for a fair, efficient and sustainable e-health ecosystem.

The conceptual framework next attempts to model the digital data flows in the e-health ecosystem based on our review and understanding of the existing ehealth business models, and the roles and relationships of the key players. This will provide an overview of the information exchanges that take place in the e-health market space, and will facilitate our analysis of the market space using the ADVISOR framework.

In our simplified model, the players on the e-health network primarily assume two roles: one of "suppliers" of health information to the network, and the other of "consumers" of health information from the network. These two roles are not mutually exclusive and often co-occur. For example, the information "supplied" by a physician in the form of EHRs may be "consumed" by another healthcare provider in the network, say a specialist or hospital, who then makes diagnoses with the health information to provide further information of 
interest to other players such as insurers and vendors. Likewise, the information supplied by a patient or healthcare consumer in the form of PHRs may be consumed and edited by others in the network authorized to do so. Such an exchange is facilitated by "infomediaries", yet another role in the network played by some players who syndicate, aggregate and distribute health information in their central repository in order to provide added value to the ecosystem. An infomediary is described as a neutral, unbiased, third party entity that functions as an information conduit and as a business matchmaker [84], creating in the process, a novel kind of information supply chain [85].

In essence, an e-health infomediary acts as a broker that brings together or bridges various players who would otherwise belong to a highly fragmented market place, and facilitates seamless digital flows among them. Figure 2 shows some of the significant digital information flows that are fostered by these infomediaries in the e-health ecosystem.

We have categorized the digital flows as information-based and transaction-based flows. Information flows denote the information supplied to and consumed by the key players in the e-health network. Transaction flows on the other hand, denote business transactions among the key players. For instance, information flows may include exchange of EHRs between providers, or between a provider and a payer or vendor. Likewise, PHRs can also be exchanged by a patient or consumer with providers, payers and vendors. Transaction flows involve ecommerce and may include instances like a provider purchasing medical supplies from a vendor, or a patient or consumer purchasing products from a vendor or services from a provider.

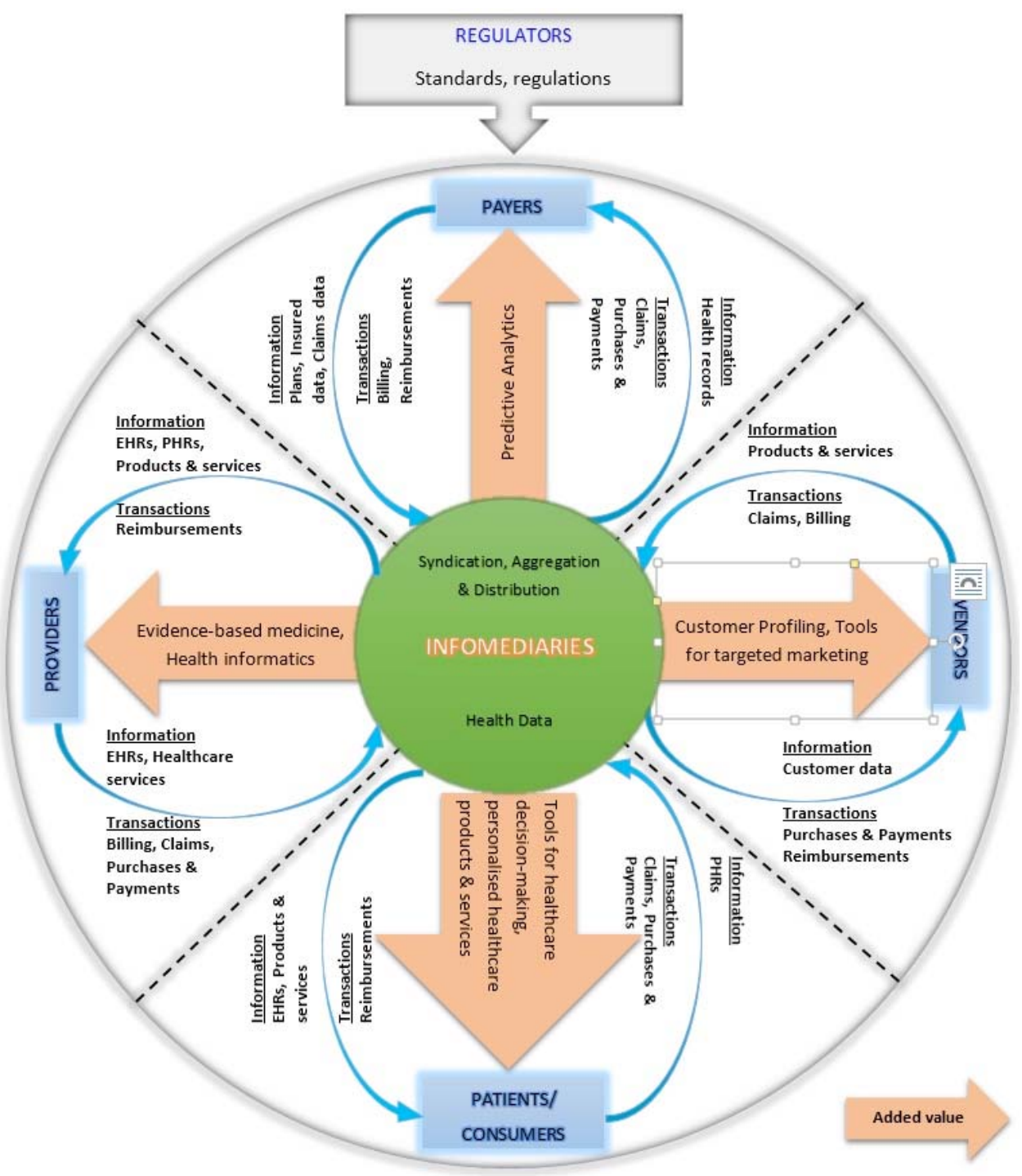

Figure 2: E-health Digital Flows. 
In addition to mapping the digital flows, we have also identified the added values that potentially accrue to every player on account of these digital exchanges through the e-health platform. The conceptual model outlined above will next be used to analyze the e-health ecosystem.

\section{USING THE ADVISOR FRAMEWORK}

\subsection{Modeling E-Health Flows}

Having shown key digital flows in the e-health market space, we next examine the key design parameters of each of the e-health players in order to analyze how and why they would collaborate for value rather than compete for revenues. This is accomplished by applying the ADVISOR framework to the e-health market space as summarized in Table 2. At the level of each ADVISOR element, the table shows the value created for the ecosystem from a player's digital contribution. The analysis is from the perspective of each of the key players identified in the e-health ecosystem except for the Regulators, who are not-for-profit entities and who therefore cannot be subject to a business model framework.

Table 2: Analysis of E-health Ecosystem with ADVISOR

\begin{tabular}{|c|c|c|c|c|c|c|c|}
\hline \multicolumn{8}{|c|}{ Key E-Health Players } \\
\hline & $\begin{array}{l}\text { Patients } \\
\text { (Consumers) }\end{array}$ & Providers & & Payers & Vendors & & Infomediaries \\
\hline $\begin{array}{l}\text { Value } \\
\text { Proposition }\end{array}$ & $\begin{array}{c}\text { Patient-centric } \\
\text { healthcare facilitated } \\
\text { by PHRs and other } \\
\text { healthcare decision- } \\
\text { making tools }\end{array}$ & $\begin{array}{l}\text { Evidence-based } \\
\text { medicine } \\
\text { facilitated by } \\
\text { electronic health } \\
\text { records }\end{array}$ & & $\begin{array}{l}\text { Efficient claims } \\
\text { handling and } \\
\text { imbursements and } \\
\text { etter risk modeling }\end{array}$ & $\begin{array}{l}\text { Direct, targeted } \\
\text { marketing of products } \\
\text { and services to } \\
\text { healthcare customers }\end{array}$ & & $\begin{array}{l}\text { platform facilitating } \\
\text { change and reuse of } \\
\text { health information } \\
\text { hich reduces costs } \\
\text { and improves } \\
\text { efficiencies for all }\end{array}$ \\
\hline Interface & \multicolumn{7}{|c|}{$\begin{array}{l}\text { Web interface that allows for interoperability across multiple platforms and exchange of data residing in multiple } \\
\text { locations }\end{array}$} \\
\hline Service Platform & \multicolumn{7}{|c|}{$\begin{array}{l}\text { Multi-tenant architecture that supports multiple concurrent users and offers high security features like encryption, } \\
\text { authentication and access levels, to protect health data; cloud computing technologies }\end{array}$} \\
\hline $\begin{array}{l}\text { Organizing } \\
\text { Model }\end{array}$ & \multicolumn{7}{|c|}{$\begin{array}{l}\begin{array}{l}\text { Standards and certifications for interoperability of health information systems and seamless exchange of health data } \\
\text { (e.g. HL7, Dicom etc.) }\end{array} \\
\text { Regulations to protect privacy and security of health data and curb its commercial exploitation (e.g. HIPAA) }\end{array}$} \\
\hline Revenues / Cost & $\begin{array}{l}\text { Cost: Free or small } \\
\text { subscription fee } \\
\text { Revenues: Usually } \\
\text { none, with some } \\
\text { possibility for C2C } \\
\text { commerce }\end{array}$ & $\begin{array}{l}\text { Cost: Investment } \\
\text { EHR systems, train } \\
\text { costs, maintenanc } \\
\text { upgrading costs } \\
\text { Revenues: B2B ar } \\
\text { B2C ecommerce } \\
\text { reimbursements }\end{array}$ & & $\begin{array}{l}\text { Cost: Investment ir } \\
\text { payer information } \\
\text { system, training } \\
\text { costs, maintenance } \\
\text { \& upgrading costs } \\
\text { Revenues: B2B, an } \\
\text { B2C ecommerce }\end{array}$ & $\begin{array}{c}\text { Cost: Investment i } \\
\text { information system } \\
\text { training costs, } \\
\text { maintenance \& } \\
\text { upgrading costs } \\
\text { Revenues: B2B, B } \\
\text { ecommerce, } \\
\text { reimbursements }\end{array}$ & & $\begin{array}{l}\text { Cost: Investment in } \\
\text { IT infrastructure for } \\
\text { standards-based, } \\
\text { secure exchange } \\
\text { of health data. } \\
\text { Revenues: } \\
\text { Subscription fees, } \\
\text { advertisement } \\
\text { revenues, } \\
\text { ecommerce } \\
\text { transactions }\end{array}$ \\
\hline $\begin{array}{l}\text { Adoption by } \\
\text { Users }\end{array}$ & $\begin{array}{l}\text { Co-creation of value } \\
\text { through PHRs, a } \\
\text { source of } \\
\text { empowerment in } \\
\text { healthcare decision- } \\
\text { making }\end{array}$ & $\begin{array}{l}\text { Co-creation of valt } \\
\text { through EHRs whi } \\
\text { improve efficiencie } \\
\text { and reduce medic } \\
\text { errors and resultir } \\
\text { litigation costs }\end{array}$ & & $\begin{array}{l}\text { Co-creation of valu } \\
\text { through aggregatio } \\
\text { of insured and } \\
\text { claims data which } \\
\text { facilitates superior } \\
\text { risk modeling }\end{array}$ & $\begin{array}{l}\text { Co-creation of valu } \\
\text { through targeted } \\
\text { marketing which } \\
\text { significantly reduce } \\
\text { direct marketing co }\end{array}$ & & $\begin{array}{l}\text { Co-creation of } \\
\text { value through } \\
\text { syndication , } \\
\text { aggregation and } \\
\text { distribution of } \\
\text { health data which } \\
\text { creates new } \\
\text { markets and } \\
\text { business } \\
\text { opportunities }\end{array}$ \\
\hline Disruptions & $\begin{array}{l}\text { Single electronic } \\
\text { interface for the } \\
\text { entire continuum of } \\
\text { healthcare } \\
\text { management in lieu } \\
\text { of multiple resource- } \\
\text { consuming face-to- } \\
\text { face interfaces }\end{array}$ & $\begin{array}{l}\text { Electronic interfac } \\
\text {-with patients in lie } \\
\text { resource-consumi } \\
\text { face-to-face interfa } \\
\text { - with payers anc } \\
\text { vendors for efficie } \\
\text { and transparent } \\
\text { transactions }\end{array}$ & & $\begin{array}{l}\text { Electronic interface } \\
\text { for insurance claim } \\
\text { and purchase of } \\
\text { plans in lieu of } \\
\text { resource-intensive } \\
\text { paper-based } \\
\text { transactions }\end{array}$ & $\begin{array}{l}\text { Single electronic } \\
\text { interface to access } \\
\text { target the gamut c } \\
\text { healthcare custome } \\
\text { healthcare provider } \\
\text { patients, insurers e }\end{array}$ & & $\begin{array}{l}\text { A well-networked } \\
\text { electronic } \\
\text { healthcare } \\
\text { marketplace in lieu } \\
\text { of the conventional, } \\
\text { fragmented } \\
\text { marketplace }\end{array}$ \\
\hline
\end{tabular}




\subsection{Values Created Vs Values Captured}

From our analysis of the e-health market space using the ADVISOR framework in Table 2, it is evident that the roles of key players are interdependent. Each player potentially creates an "added value" that benefits other players, thereby giving rise to a compelling proposition in the e-health ecosystem to collaborate to create and capture "value" rather than compete for "dollars". However the outcomes of such a proposition may vary from player to player, thus begging the question if the value captured (value added) justifies the value created (added value), for all the players involved. In other words, value created is what a player gives to an ecosystem in terms of utility whereas value captured is what a player extracts from the ecosystem in terms of payoff. Table 3 summarises the values created and captured through digital flows within the ehealth ecosystem for players that were derived from using the ADVISOR framework with corroborated support from the research literature.

E-health holds great promise for empowerment of patients who are "the largest and most important stakeholder group" [7]. It serves to open doors to competitive markets, which is bound to increase

Table 3: Values Created and Values Captured by Players

\begin{tabular}{|c|c|c|}
\hline Key Players & Values created & Values captured \\
\hline 1. Patients & $\begin{array}{c}\text { Health data [46] } \\
\text { Personal health records }[86] \\
\text { Healthcare ecommerce (B2C, C2C) }[16,63] \\
\text { Health experience sharing in peer-to-peer } \\
\text { communication }[6,87]\end{array}$ & $\begin{array}{c}\text { Ubiquitous access to health records [88] } \\
\text { Patient-centric healthcare }[88] \\
\text { Increased healthcare choices }[64,89] \\
\text { Lower healthcare costs }[14,90] \\
\text { Empowerment to make informed choices }[87,91]\end{array}$ \\
\hline 2. Providers & $\begin{array}{l}\text { Electronic medical / health records [22] } \\
\text { Improved quality of care [18] } \\
\text { Tele-healthcare delivery [7] } \\
\text { Evidence-based medicine [62] } \\
\text { Preventive healthcare [58] } \\
\text { Medical informatics [23] } \\
\text { Reduced medical errors [19] }\end{array}$ & $\begin{array}{c}\text { Improved operational efficiencies [14, 92] } \\
\text { Enhanced cost-effectiveness [19] } \\
\text { Training and education of physicians [6] } \\
\text { Cost-effective e-procurement of medical supplies [14] } \\
\text { New business opportunities created by the eHealth } \\
\text { network (B2B, B2C) [63] } \\
\text { Reduced risk of litigation [93] }\end{array}$ \\
\hline 3. Payers & $\begin{array}{c}\text { Electronic interface for claims management [18] } \\
\text { Electronic interface for direct purchase of plans by } \\
\text { customers bypassing agents [94] } \\
\text { Research and analytics facilitated by data } \\
\text { aggregation [14] } \\
\text { Targeted information delivery to customers } \\
\text { facilitated by data aggregation [63] }\end{array}$ & $\begin{array}{c}\text { Improved efficiency in claims handling }[14,18,26] \\
\text { Easier implementation of healthcare regulations [14] } \\
\text { Increased business opportunities (B2B, B2C etc.) due } \\
\text { to direct access to a large pool of healthcare } \\
\text { customers [63] }\end{array}$ \\
\hline 4. Third-Party Vendors & $\begin{array}{l}\text { Direct access to products / services for customers } \\
\text { through ecommerce [14, 95] } \\
\text { Personalized products and services facilitated by } \\
\text { data aggregation [63] } \\
\text { R\&D data [96] }\end{array}$ & $\begin{array}{l}\text { Electronic interface to access and target the gamut of } \\
\text { healthcare customers - healthcare providers, patients, } \\
\text { insurers etc. [14] } \\
\text { Decreased marketing costs [14] } \\
\text { Reduced R \& D costs [14] } \\
\text { Increased business opportunities (B2B, B2C etc.) due } \\
\text { to direct access to a large pool of healthcare } \\
\text { customers [6,97] }\end{array}$ \\
\hline 5. Infomediaries & $\begin{array}{c}\text { Total digital health systems [23] } \\
\text { A digital platform to facilitate exchange and reuse } \\
\text { of health data among players in the healthcare } \\
\text { market [71, 72] } \\
\text { Improved efficiencies for players in the healthcare } \\
\text { market [14] } \\
\text { Reduced costs for players in the healthcare } \\
\text { market }[14] \\
\text { Big data }[96,98]\end{array}$ & $\begin{array}{l}\text { New markets brought about by syndication, } \\
\text { aggregation and distribution of health data [71] } \\
\text { New business opportunities and revenues to be } \\
\text { tapped in the form of subscription fees, advertisement } \\
\text { revenues, ecommerce transactions [6], [63] }\end{array}$ \\
\hline 6. Regulators & $\begin{array}{l}\text { Incentives to facilitate EHR adoption and health } \\
\text { information exchange [99,52] } \\
\text { Regulations to protect privacy / security of health } \\
\text { data [73] } \\
\text { Standards for interoperable healthcare systems to } \\
\text { facilitate exchange and reuse of health data [100] }\end{array}$ & $\begin{array}{c}\text { Improved health of populations [73] } \\
\text { Improvement in quality of healthcare [73] } \\
\text { Improved efficiency of healthcare systems [73] } \\
\text { Lower healthcare expenditure [7] }\end{array}$ \\
\hline
\end{tabular}


healthcare choices [89] and lower healthcare costs [14, 90]. Equipped with ubiquitous access to PHRs, EHRs and tools for informed healthcare decision-making and guided health promotion behaviors [88], healthcare consumers will have complete freedom to choose and switch among multiple care providers while seeking to satisfy their unique needs for quality, service, and price [64].

A 2007 survey of US consumers by Accenture found that healthcare consumers consider the presence of EHRs an important factor in their choice of a physician. Another 2009 study by User Centric on the comparative usability of two cloud-based PHR applications reported that the majority of its study participants found PHRs useful and expressed interest in creating and maintaining their own PHRs. This rise of consumerism coupled with policy imperatives by some governments, forces healthcare providers to focus on the needs and demands of consumers, and consequently make hefty investments in EHR systems.

No doubt this is a burden on the healthcare providers in the short term, but the value they can leverage from this investment over the long term is compelling. When e-health fosters evidence-based medicine [62] with the support of medical informatics, it enhances the quality of care; improves operational efficiencies; reduces medical errors [7, 43, 101]; facilitates training and education of physicians and cost-effective e-procurement of medical supplies [6]; increases reimbursements [102] and provides access to a larger pool of healthcare consumers by opening up new business opportunities (e.g. authoring personalized healthcare plans).

The e-health benefits that accrue to Payers are also significant - improved efficiency in claims processing resulting in cost savings $[14,18,26]$ easier implementation of regulations such as HIPAA [14], reduced wasteful reimbursements on account of redundant tests [100], online sale of health insurance bypassing agents [94] and research and analytics enabled by the massive stores of data aggregated in the e-health network [14].

The diverse range of healthcare Vendors also stand to benefit from e-health in terms of the enormous potential for B2B and B2C ecommerce opportunities it offers [97]. They enjoy better visibility of their offerings, and gain direct access to their customers via ecommerce [95], and in turn decreasing their marketing costs [14]. Additionally, they are also equipped with tools to do targeted marketing of their products and services to prospective customers.

For the infomediary, the value in e-health, is the opportunity to syndicate, aggregate and distribute the massive amounts of data in the network referred to as 'big data' [96, 98], to cater to the varying needs of the other players, thereby creating new business opportunities and markets [71, 72]. By facilitating such exchange and reuse of health data [103], it improves efficiencies and reduces costs for every player in the network, while at the same time generating revenues for itself through such value creation. We posit that infomediaries already in the cloud (e.g. Microsoft Health Vault) will emerge as the most dominant infomediaries in the e-health ecosystem, with the takeoff of cloud computing technologies in the healthcare sector.

As for the regulators, they drive the standards required to facilitate interoperability among health systems so health data can be exchanged and reused [100], as well as the regulations to protect the privacy and security of health data, and prevent any unauthorized exploitation of such data by other players in the network [73]. In addition, regulators may also offer financial incentives to healthcare providers to encourage adoption of EHR systems by reducing their financial burden in such investments [52, 99].

At the level of the ecosystem, we may expect that for a fair, efficient, stable and sustainable e-health market space, it is critical that the participation of each player be justified in creating utility for the ecosystem in exchange for a compelling value that can be captured from the other involved players. As already discussed game theory provides a systematic way to understand the behavior of players in situations of interdependent fortunes [104, 105] such as the e-health ecosystem modelled in this paper. The essence of a game is the interdependence of the players' decisions [106], which for instance, in the context of e-health, may mean a key player's decision to participate and create values in the ecosystem, or not. If the healthcare providers for example are not motivated to participate in e-health and create values in the form of EHRs, significant values may be lost for the ecosystem therefore making it unsustainable. For every key player to be motivated to participate and create value in the e-health ecosystem there must be fairness in terms of the values that can be captured from the ecosystem.

The notion of fairness is to ensure that all players in a game get a fair treat in their interactions, agreements 
or situations. According to Grandori [107], fairness denotes rules or criteria used to divide valuable resources for apportionment to the different players. Four rules have been suggested, out of which, the input-output criteria may be more relevant in the context of the e-health ecosystem. This rule states that fairness is the correspondence between the pay-off received by a player and its contribution to the achievement of the total output. As applied in the context of e-health, this translates to every player being able to capture values in proportion to the value it creates in the network. Such fairness is essential to keep the players engaged to the ecosystem, so the benefits of e-health can be fully harnessed.

The notion of efficiency may conflict with the notion of fairness in the digital media industry which is characterized by intense competition resulting from reduced information asymmetries. In healthcare, resource misallocations are massive owing to the lack of uniform and transparent information in the marketplace. Some key players have remarkable incentives to hoard information and leverage the asymmetry to extract profits. A case in point is the healthcare providers who have more incentive to institutionalize patient data than share with other players. The consequence is a serious lack of coordinated care, the brunt of which has to be borne by healthcare consumers [77]. The e-health ecosystem is bound to significantly reduce such asymmetries and improve market transparency and efficiency, but it may not provide the financial stimulus for such players to participate in the ecosystem. The ecosystem may be sustainable only if the right trade-off between efficiency and fairness is achieved. Another possibility worth investigating is whether the ecosystem may still be sustainable if at the least, no player is worse off than status quo because of their participation in the ecosystem, and at least one player (healthcare consumers) is better off. Such an outcome is referred to as 'Pareto-optimal'. A Pareto-optimal outcome is one that cannot be improved upon without hurting at least one player [108]. However, whether this notion would hold good in the context of e-health, remains to be investigated.

In all of the above described scenarios, the central issue is - how is value apportioned among the players? A less than fair and efficient apportionment of value is not sustainable (and therefore not stable). We posit that until and unless there is value symmetry between players and the ecosystem, healthcare over a cloud would not be feasible. It is also clear that if seeking digital information and value asymmetry is the pervasive tactic of many players in the ecosystem, then the situation known as a tragedy of the commons is inevitable. Here, self-serving tactics from players remove the incentive for individual value creation and there is little value to capture from the ecosystem.

\section{AGENDA FOR FURTHER RESEARCH}

By deriving value through shared resources and cocreation among the key players, e-health has the potential to effectively integrate the fragmented healthcare market and promote collaboration amongst the players. This creates a symbiotic network where each player brings an "added value" which is captured by the other players. In simplified terms, this translates to each player capturing values that are multipliers of the value they create. By opting out of this game, a player stands more to lose than gain. Such a compelling proposition makes for a fair, efficient and stable e-health market space. As e-health evolves and its players reap the benefits and realize success, ehealth implementations will inevitably be more widespread. It is probably a matter of time before healthcare is consumed as a utility, similar to other precedents like entertainment, education, banking etc. In a nutshell, what this implies is the importance of the role of an e-health regulator (perhaps akin to various gaming commissions) who enforces compliance of mutually agreed upon cost and revenue splits among players and payers. It remains to be seen whether the government (e.g. the Affordable Care Act of the United States or the National Health Services of the United Kingdom), or the players themselves establishing such a commission in the style of self-regulation, or a third party e-healthcare infomediary is best poised to be effective in this role. But the fundamental tenet that players capture the value they create is a convincing one.

Some limitations of the study are acknowledged at this point. The scope of e-health considered for this paper was limited to a TDHS that connects the key players electronically via internet, whereas in the actual sense, e-health is a much broader term that encompasses more than just Internet and medicine. It is not just a technical development, but also a "state-ofmind, a way of thinking, an attitude, and a commitment for networked, global thinking, to improve healthcare locally, regionally, and worldwide by using information and communication technology" [16, pp.20]. E-health is after all $80 \%$ health and $20 \%$ ICT (Al-Nuaim, 2009) ${ }^{6}$.

${ }^{6}$ Al-Nuaim, H.A. (2009). Personal Communication. 
The digital flows modeled in this paper are by no means exhaustive and only capture the major digital exchanges possible among the e-health players.

Further research is suggested to unlock the latent value of e-health technologies by discovering a logic than can align the technical potential of e-health with realization of benefits for all its stakeholders. This logic or 'heuristic logic' is what is referred to as a business model [109]. It is the blueprint of how a business can be organized to the benefit of all the stakeholders. Although it stands to reason that e-health will succeed if all of the major players are able to create and correspondingly capture value in a supportive regulatory regime, this remains to be shown as there is no demonstrable evidence as yet. It is hoped that this

\section{APPENDIX}

\section{Expert Interview Template}

Dear Sir / Madam,

I am a doctoral student from Nanyang Technological University, Singapore. I am working in the area of e-health, and in particular, my research interest is in e-health business models. I have done some preliminary work on the e-health ecosystem, based on which I have identified the primary healthcare market players and the values they create $^{*}$ and capture ${ }^{*}$ in the e-health market space. I am writing to seek help from knowledgeable practitioners like you, to validate my preliminary work which was primarily based on literature and industry observations. Such validation will help me focus my research efforts on the key players in e-health and the really critical issues facing them. I sincerely hope you will be able to assist me in this research.

Please let me have your judgement after carefully going through the background provided below.

\section{I: E-Health Ecosystem}

The healthcare market has players at two levels - primary and secondary. At the primary level of the healthcare continuum are market players who use health information to provide patient care directly or indirectly (by supporting direct providers of patient care). These primary healthcare market players have been described in the table below:

Table 1: Primary Healthcare Market Players

\begin{tabular}{|c|c|}
\hline Players & Role \\
\hline \hline Patients & $\begin{array}{c}\text { Recipients of health services, often labeled by their financial status: insured or uninsured, privately or publicly } \\
\text { insured, with or without financial assets, etc. for the purposes of Financial Case Management }{ }^{7} \text { and Clinical Case } \\
\text { Management }\end{array}$ \\
\hline Providers & $\begin{array}{r}\text { Any clinical setting and professional staff that designs, implements, and/or executes any healthcare initiative which } \\
\text { may be part of a wellness or illness program (Busch, 2008). }\end{array}$ \\
\hline Third-Party Vendors & $\begin{array}{r}\text { A large group of diverse market players who play a supporting role to the Providers in their provision of healthcare. } \\
\text { These players include health IT vendors, medical equipment vendors, pharmaceutical vendors, transportation } \\
\text { services, laboratories, legal systems, billing agents etc. (Busch, 2008). }\end{array}$ \\
\hline
\end{tabular}

\footnotetext{
${ }^{7}$ Discipline of creating a financial plan to meet the patient's healthcare needs (Busch, 2008)

${ }^{8}$ Includes current healthcare initiatives and past treatment regimes (Busch, 2008)
}

study will be a step in that direction, and make a significant contribution towards the design of a fair, efficient and sustainable e-health ecosystem.

\section{ACKNOWLEDGEMENTS}

The research reported in this article was part of the doctoral dissertation of Ms Felix Lena Stephanie. Digital Media programme. Dr Ravi Sharma served as the Principal Investigator of the Special Interest Group on Interactive Digital Enterprise (SIGIDE). The authors are grateful to the members of SIGIDE as well as the practitioners who were interviewed for sharing their insights, comments and feedback. 


\begin{tabular}{|c|c|}
\hline Payers & $\begin{array}{c}\text { Any entity that processes the claims payment transactions of healthcare episodes on behalf of plan sponsors. A } \\
\text { plan sponsor is an entity that funds a health program - private insurance plans, government-sponsored plans, } \\
\text { employer-sponsored plans etc. (Busch, 2008). }\end{array}$ \\
\hline Infomediaries & $\begin{array}{r}\text { Organizations that gather pertinent health information from various sources, and syndicate, aggregate and } \\
\text { distribute it to foster patient-centric health care (Busch, 2008; Morales-Arroyo \& Sharma, 2009). }\end{array}$ \\
\hline Regulators & $\begin{array}{c}\text { Public and private organizations that develop capabilities for standards-based, secure and confidential exchange } \\
\text { of health information to improve the coordination of care among the e-health market players (Blumenthal, 2009). }\end{array}$ \\
\hline
\end{tabular}

*The terms "value created" and "value captured" are defined on page 3, in section Background II.

Secondary market players on the other hand, use health information in roles other than direct and indirect patient care activities. These are public and private organizations focusing on public health, patient autonomy and clinical case management activities (Busch, 2008).

Based on this background, we have attempted to diagrammatically represent the e-health ecosystem which is as shown in Figure 1.

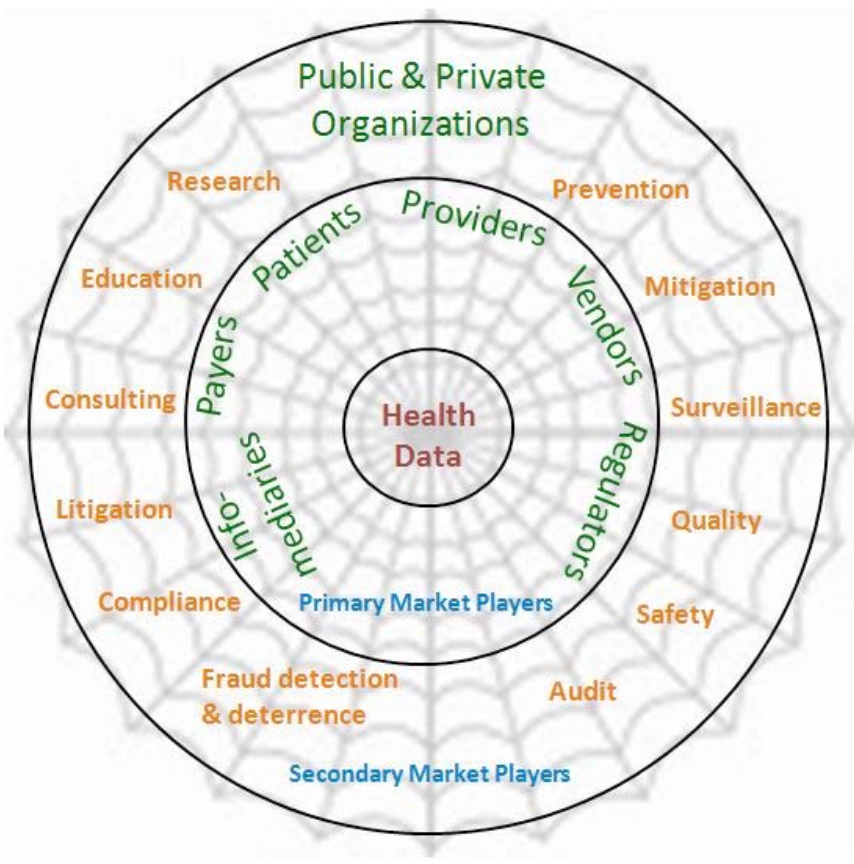

Figure 1: E-Health Ecosytem.

\section{Questions}

In your judgment, would you agree with our identification of the six primary healthcare market players? Please point out any omissions or redundancies and state your reason(s) correspondingly.

Does the e-health ecosystem above adequately model reality?

Would it be a fair assessment to state that e-health would only work if it brings about cost efficiency as well as improved services? 


\section{II: Value created vs. value captured by primary healthcare market players}

Value is "created" when a player develops its core competencies, capabilities and advantages to perform work activities that differentiate it from competitors, and "captured" when the firm derives economic returns in relation to the value it creates (Shafer et al., 2005).

In the context of e-health, every player in e-Health "creates a value" that benefits other players, thereby giving rise to a compelling proposition in the e-health market space to collaborate to "create and capture value" rather than "compete for dollars". However the outcomes of such a proposition may vary from player to player, thus begging the question if the "value captured" justifies the "value created", for all the players involved.

For a sustainable e-health market space, it is critical that the participation of each player be justified in "creating" values for the network in exchange for a compelling value that can be "captured" from the network.

\section{Table 2: Value Created Vs. Value Captured}

\begin{tabular}{|c|c|c|}
\hline $\begin{array}{l}\text { Primary Healthcare } \\
\text { Market } \\
\text { Players }\end{array}$ & Value created & Value captured \\
\hline 2. Providers & $\begin{array}{l}\square \text { Electronic medical / health records (Hill et al., 2007) } \\
\square \text { Improved quality of care (Walker et al, 2005) } \\
\square \text { Tele-healthcare delivery (Hill \& Powell, 2009) } \\
\square \text { Evidence-based medicine (Busch, 2008) } \\
\square \text { Preventive healthcare (Chang et al., 2009) } \\
\square \text { Medical informatics (Raghupathi \& Kesh, 2009) } \\
\square \text { Reduced medical errors (Vishwanath \& Scamurra, } \\
\text { 2007) }\end{array}$ & $\begin{array}{l}\square \text { Improved operational efficiencies (Wen \& Tan, 2003) } \\
\square \text { Enhanced cost-effectiveness (Vishwanath \& } \\
\text { Scamurra, 2007) } \\
\square \text { Training and education of physicians } \\
\text { (Wickramasinghe et al., 2005) } \\
\square \text { Cost-effective e-procurement of medical supplies } \\
\text { (Wen \& Tan, 2003) } \\
\square \text { New business opportunities created by the eHealth } \\
\text { network (B2B, B2C) (Parente, 2000) }\end{array}$ \\
\hline $\begin{array}{l}\text { 3. Third-Party } \\
\text { Vendors }\end{array}$ & $\begin{array}{l}\square \text { Direct access to products / services by customers (Wen } \\
\& \text { Tan, 2003) } \\
\square \text { Targeted marketing facilitated by data aggregation } \\
\text { (Parente, 2000) }\end{array}$ & $\begin{array}{l}\square \text { Electronic interface to access and target the gamut of } \\
\text { healthcare customers - healthcare providers, patients, } \\
\text { insurers etc. (Wen \& Tan, 2003) } \\
\square \text { Decreased marketing costs (Wen \& Tan, 2003) } \\
\square \text { Reduced R \& D costs (Wen \& Tan, 2003) } \\
\square \text { Increased business opportunities (B2B, B2C etc.) due } \\
\text { to direct access to a large pool of healthcare customers } \\
\text { (Payton, 2003) }\end{array}$ \\
\hline 4. Payers & $\begin{array}{l}\square \text { Electronic interface for claims management (Walker et } \\
\text { al., 2005) } \\
\square \text { Electronic interface for direct purchase of plans by } \\
\text { customers bypassing agents (Whitten et al., 2001) } \\
\square \text { Research and analytics facilitated by data aggregation } \\
\text { (Wen \& Tan, 2003) } \\
\square \text { Targeted information delivery to customers facilitated by } \\
\text { data aggregation (Parente, 2000) }\end{array}$ & $\begin{array}{l}\square \text { Improved efficiency in claims handling (Wen \& Tan, } \\
\text { 2003) } \\
\square \text { Cost savings (Walker et al., 2005) } \\
\square \text { Easier implementation of healthcare regulations (Wen } \\
\text { \& Tan, 2003) } \\
\square \text { Increased business opportunities (B2B, B2C etc.) due } \\
\text { to direct access to a large pool of healthcare customers } \\
\text { (Parente, 2000) }\end{array}$ \\
\hline
\end{tabular}




\begin{tabular}{|l|l|l|}
\hline 5. Infomediaries & $\begin{array}{l}\square \text { Total digital health systems (Raghupathi \& Kesh, 2009) } \\
\square \text { A digital platform to facilitate exchange and reuse of } \\
\text { health data among players in the healthcare market } \\
\text { (Raghupathi \& Kesh, 2009; Morales-Arroyo \& Sharma, } \\
2009) \\
\square \text { Improved efficiencies for players in the healthcare } \\
\text { market (Wen \& Tan, 2003) } \\
\square \text { Reduced costs for players in the healthcare market } \\
\text { (Wen \& Tan, 2003) }\end{array}$ & $\begin{array}{l}\square \text { New markets brought about by syndication, } \\
\text { aggregation and distribution of health data (Morales- } \\
\text { Arroyo \& Sharma, 2009) } \\
\square \text { New business opportunities and revenues to be } \\
\text { tapped in the form of subscription fees, advertisement } \\
\text { revenues, ecommerce transactions (Parente, 2000) }\end{array}$ \\
\hline 6. Regulators & $\begin{array}{l}\square \text { Improvement in quality of healthcare (Blumenthal, } \\
\text { 2009) } \\
\text { Regulations to protect privacy / security of health data } \\
\text { (Blumenthal, 2009) } \\
\square \text { Standards for interoperable healthcare systems to } \\
\text { facilitate exchange and reuse of health data (Goldstein, } \\
\text { 2009) }\end{array}$ & $\begin{array}{l}\square \text { Improved health of populations (Blumenthal, 2009) } \\
\text { Improved efficiency of healthcare systems } \\
\text { (Blumenthal, 2009) }\end{array}$ \\
\hline
\end{tabular}

\section{Questions}

The following questions pertain to Table 2.

Do you think we have adequately identified the sources of values created and captured by the six primary healthcare market players? If not, please state the player(s) and specify your reason(s).

Please state the player(s) and specify your reason(s).

Do you think the "value created" is typically less than the "value captured" for some players? Please state the player(s) and specify your reason(s).

In your judgement, who among the six players captures the greatest value from e-health? And who creates the greatest value?

In your judgement, who among the six players captures the least value from e-health? And who creates the least value?

Creating more value than a player captures is not sustainable. Do you agree? 
Capturing more value than a player creates may be profitable for a given time, but not sustainable in the long run. Do you agree?

The e-health eco-system can grow only if there is fairness and efficiency. Do you agree?

Thank you for sharing your expert views.

\section{REFERENCES}

[1] Gubbins E. How telcos could conquer the cloud 2009. ConnectedPlanetOnline.com. Retrieved May 6, 2010 from http://connectedplanetonline.com/business_services/news/cl oud-computing-telecom-service-providers-0401/

[2] Narayanan HAJ, Günes MH. Ensuring access control in cloud provisioned healthcare systems. Consumer Communications and Networking Conference (CCNC) 2011; IEEE, 247-251.

http://dx.doi.org/10.1109/CCNC.2011.5766466

[3] Shimrat O. Cloud Computing and Healthcare: Bad Weather or Sunny Forecast? San Diego Physician 2009; 26-29.

[4] Kuo AM-H. Opportunities and Challenges of Cloud Computing to Improve Health Care Services [Electronic Version]. Journal of Medical Internet Research 2011; 13(3): e67.

http://dx.doi.org/10.2196/jmir.1867

[5] Webb G. Making the cloud work for healthcare. (cover story). Health Management Technology 2012; 33(2): 8-9.

[6] Wickramasinghe NS, Fadlalla AMA, Geisler E, Schaffer JL. A framework for assessing e-health preparedness. International Journal of Electronic Healthcare 2005; 1(3): 316-334.

http://dx.doi.org/10.1504//JEH.2005.006478

[7] Hill JW, Powell P. The national healthcare crisis: Is eHealth a key solution? Business Horizons 2009; 52(3): 265-277. http://dx.doi.org/10.1016/j.bushor.2009.01.006

[8] Black AD, Car J, Pagliari C, Anandan C, Cresswell K, et al. The Impact of eHealth on the Quality and Safety of Health Care: A Systematic Overview. PLoS Med 2011; 8(1): e1000387.

http://dx.doi.org/10.1371/journal.pmed.1000387

[9] Kellermann AL, Jones SS. What it will take to achieve the asyet-unfulfilled promises of health information technology. Health Affairs 2013; 32(1): 63-8. http://dx.doi.org/10.1377/hlthaff.2012.0693

[10] Dyer KA, Thompson CD. Medical Internet Ethics: A Field in Evolution. In V.L. Patel, R. Rogers \& R.Haux (Eds.), Medlnfo. Amsterdam: IOS Press 2001; pp. 1287-1291.

[11] Bulgiba AM. Information Technology in Health Care - What the Future Holds. Asia-Pacific Journal of Public Health 2004; 16(1): 64-71. http://dx.doi.org/10.1177/101053950401600111

[12] Tripathi M, Delano D, Lund B, Rudolph L. Engaging Patients for Health Information Exchange. Health Affairs 2009; 28(2): 435-443.

http://dx.doi.org/10.1377/hlthaff.28.2.435

[13] Parmar R, Mackenzie I, Cohn D, Gann D. The New Patterns of Innovation. Harvard Business Review 2014; 92(1/2): 8695.
[14] Wen HJ, Tan J. The evolving face of telemedicine \& e-health: opening doors and closing gaps in e-health services opportunities \& challenges. Proceedings of the 36th Annual Hawaii International Conference on System Sciences 2003. http://dx.doi.org/10.1109/hicss.2003.1174374

[15] Clancy CM, Anderson KM, White PJ. Investing in Health Information Infrastructure: Can It Help Achieve Health Reform? Health Affairs 2009; 28(2): 478-482. http://dx.doi.org/10.1377/hlthaff.28.2.478

[16] Eysenbach G. What is e-health? Journal of Medical Internet Research 2001; 3(2): 20. http://dx.doi.org/10.2196/jmir.3.2.e20

[17] Baur A, Fehr J, Mayer C, Pawlu C, Schaudel F. Health care beyond medicine: Meeting the demand for new forms of care [Electronic Version]. Health International 2011; 56-63. Retrieved 02/04/2014, from http://www.mckinsey.com/ search.aspx?q=Health+care+beyond+medicine

[18] Walker J, Pan E, Johnston D, Adler-Milstein J, Bates D, Middleton B. The Value of Health Care Information Exchange and Interoperability. Health Affairs 2005; 24: 10-18. http://dx.doi.org/10.1377/hlthaff.w5.10

[19] Vishwanath A, Scamurra SD. Barriers to the adoption of electronic health records: using concept mapping to develop a comprehensive empirical model. Health Informatics Journal 2007; 13(2): 119-134.

http://dx.doi.org/10.1177/1460458207076468

[20] Ebel T, George K, Larsen E, Neal E, Shah K, Shi D. Strength in unity: The promise of global standards in healthcare [Electronic Version] 2012. Retrieved 02/04/2014, from http://www.mckinsey.com/insights/health_systems_and_servi ces

[21] Bandyopadhyay S, Ozdemir Z, Barron J. The Future of Personal Health Records in the Presence of Misaligned Incentives. Communications of the Association for Information Systems 2012; 31: 155-166.

[22] Hill JW, Langvardt AW, Massey AP. Law, information technology, and medical errors: Toward a national healthcare information network approach to improving patient care and reducing medical malpractice costs. Journal of Law, Technology \& Policy 2007; 2007(2): 159-238.

[23] Raghupathi W, Kesh S. Designing Electronic Health Records Versus Total Digital Health Systems: A Systemic Analysis. Systems Research and Behavioral Science 2009; 26: 63-79. http://dx.doi.org/10.1002/sres.918

[24] Blumenthal D, Tavenner M. The "Meaningful Use" Regulation for Electronic Health Records. New England Journal of Medicine 2010; 363(6): 501-504. http://dx.doi.org/10.1056/NEJMp1006114

[25] Lohr S. Who Pays for Efficiency? The New York Times 2007 Retrieved September 23, 2009 from http://www.nytimes.com/ 2007/06/11/business/businessspecial3/11save.html?_r=1\&re $\mathrm{f}=$ businessspecial3 
[26] Menachemi N, Collum T. Benefits and drawbacks of electronic health record systems. Risk Management and Healthcare Policy 2011; 4: 47-55. http://dx.doi.org/10.2147/RMHP.S12985

[27] Catalino J. Software solutions can trim rising costs. Health Management Technology 2010; 10-11.

[28] Osborne M, Rubinstein A. A course in game theory. Cambridge, Mass. [u.a.]: MIT Press 1994.

[29] Myerson R. Game theory. Cambridge, Mass.: Harvard University Press 1991.

[30] Luce R, Raiffa H. Games and decisions. New York: Wiley 1957.

[31] Rapoport A, Chammah A. Prisoner's dilemma. Ann Arbor: Univ. of Michigan Press 1965.

[32] Turocy TL, von Stengel B. Game Theory. CDAM Research Report LSE-CDAM-2001-09, October 2001.

[33] Brynjolfsson E, Hitt LM. Beyond the productivity paradox. Communications of the ACM 1998; 41(8): 49-55. http://dx.doi.org/10.1145/280324.280332

[34] Devaraj S, Kohli R. Information technology payoff in the healthcare industry: A longitudinal study. Journal of Management Information Systems 2000; 16(4): 41-67. http://dx.doi.org/10.1080/07421222.2000.11518265

[35] Wiedemann LA. A look at unintended consequences of EHRs. Health Management Technology 2012; 24-25.

[36] Adler-Milstein J, Bates D. Paperless healthcare: Progress and challenges of an IT-enabled healthcare system. Business Horizons 2012; 53(2): 119-130.

http://dx.doi.org/10.1016/j.bushor.2009.10.004

[37] Albanese R, Van Fleet D. Rational Behavior in Groups: The Free-Riding Tendency. Academy Of Management Review 1985; 10(2): 244-255.

[38] Adar E, Huberman B. Free riding on Gnutella. First Monday, 2000; 5(10).

http://dx.doi.org/10.5210/fm.v5i10.792

[39] Arrow KJ. Uncertainty and the welfare economics of medical care. The American Economic Review 1963; LIII(5): 141-149.

[40] Blomqvist A. The doctor as double agent: Information asymmetry, health insurance and medical care. Journal of Health Economics 1991; 10: 411-432.

http://dx.doi.org/10.1016/0167-6296(91)90023-G

[41] Shafer SM, Smith HJ, Linder JC. The power of business models. Business Horizons 2005; 48(3): 199-207. http://dx.doi.org/10.1016/j.bushor.2004.10.014

[42] Bassi J, Lau F. Measuring value for money: a scoping review on economic evaluation of health information systems. Journal of the American Medical Informatics Association 2013; 20: 792-801. http://dx.doi.org/10.1136/amiajnl-2012-001422

[43] Chaudhry B, Wang J, Wu S, Maglione M, Mojica W, Roth E, et al. Systematic review: Impact of health information technology on quality, efficiency, and costs of medical care. Annals of Internal Medicine 2006; 144(10): 742-752. http://dx.doi.org/10.7326/0003-4819-144-10-200605160$\underline{00125}$

[44] Fleming NS, Culler SD, McCorkle R, Becker ER, Ballard DJ. The Financial and Nonfinancial Costs of Implementing Electronic Health Records in Primary Care Practices, Health Affairs 2011; 30(3): 481-489.

http://dx.doi.org/10.1377/hlthaff.2010.0768

[45] Khan M. 14 predictions for healthcare in 2014. Health Management Technology 2014; 13.

[46] Neupert P. Re-inventing Healthcare. Health Management Technology 2009; 30(3): 8-10.

[47] Sharma RS. Towards A Strategic Tool For The Business Modeling Of IDM Startups - Implementing The ADVISOR Framework. International Journal of Applied Engineering and Technology 2011; 1(1): 68-79.
[48] Sharma RS, Pereira F, Ramasubbu N. Assessing Value Creation and Value Capture in Digital Business Ecosystems. International Journal of Information Technology 2010; 16(2).

[49] Charette R. EHRs: Electronic Health Records or Exceptional Hidden Risks? Communications of The ACM 2006; 49(6): 120.

http://dx.doi.org/10.1145/1132469.1132495

[50] Regan DB, Pusatli OT, Lutton E, Athauda R. Securing an EHR in a health sector digital ecosystem. Paper presented at the Digital Ecosystems and Technologies, 2009. DEST '09. 3rd IEEE International Conference on Digital Ecosystems and Technologies 2009. http://dx.doi.org/10.1109/dest.2009.5276739

[51] Sackett DL, Rosenberg WMC, Gray JAM, Haynes RB, Richardson WS. Evidence Based Medicine: What It Is And What It Isn't: It's About Integrating Individual Clinical Expertise And The Best External Evidence. BMJ: British Medical Journal 1996; 312(7023): 71-72. http://dx.doi.org/10.1136/bmj.312.7023.71

[52] Jacob JA. Financial incentives are spurring growth of electronic health records BMJ 2013; 347: 44901.

http://dx.doi.org/10.1136/bmj.f4901

[53] Sittig DF, Singh H. Electronic Health Records and National Patient-Safety Goals. New England Journal of Medicine 2012; 367(19): 1854-1860.

http://dx.doi.org/10.1056/NEJMsb1205420

[54] Goldman D. Electronic health records: A check up 2009. CNNMoney.com. Retrieved October 29, 2009 from http://money.cnn.com/2009/07/02/news/economy/stimulus_el ectronic_health_records

[55] Thomas K. Q \& A. Healthcare Financial Management, 2013; 67(11): 64-68. Retrieved from http://search.proquest.com/ docview $/ 1461712328$ ? accountid=12665

[56] Yellowlees PM, Marks SL, Hogarth M, Turner S. StandardsBased, Open-Source Electronic Health Record Systems: A Desirable Future for the U.S. Health Industry. Telemedicine and e-Health 2008; 14(3): 284-288. http://dx.doi.org/10.1089/tmj.2007.0052

[57] Saleem JJ, Flanagan ME, Wilck NR, Demetriades J, Doebbeling BN. The next-generation electronic health record: perspectives of key leaders from the US Department of Veterans Affairs. Journal of the American Medical Informatics Association 2013; 20(e1): e175-e177.

[58] Chang HH, Chou PB, Ramakrishnan S. An Ecosystem Approach for Healthcare Services Cloud, IEEE International Conference on e-Business Engineering (ICEBE '09) 2009.

[59] Showell C, Nohr C. How Should We Define eHealth, and Does the Definition Matter? 2012. Retrieved 08/09/2014, from http://ebooks.iospress.nl/volume/quality-of-life-throughquality-of-information

[60] Baur C. An Analysis of Factors Underlying E-Health Disparities. Cambridge Quarterly of Healthcare Ethics 2008; 17: 417-428.

http://dx.doi.org/10.1017/S0963180108080547

[61] Amatayakul MK. Electronic Health Records: A Practical Guide for Professionals and Organizations. Chicago, IL: American Health Information Management Association 2009.

[62] Busch RS. Electronic Health Records: An Audit and Internal Control Guide. New Jersey: John Wiley \& Sons, Inc. 2008.

[63] Parente ST. Beyond The Hype: A Taxonomy of E-Health Business Models. Health Affairs 2000; 19(6): 89-102. http://dx.doi.org/10.1377/hlthaff.19.6.89

[64] Joslyn JS. Healthcare E-Commerce: Connecting with Patients. Journal of Healthcare Information Management 2001; 15(1): 73-84.

[65] Aggarwal AK, Travers S. E-Commerce in Healthcare: Changing the Traditional Landscape. Journal of Healthcare Information Management 2001; 15(1): 25-36. 
[66] Konrad W, Peter H. Balancing of Benefits and Disadvantages using IT-Integration to Support the Health Care value-added Chain. Paper presented at the European Conference on eHealth 2007, Oldenburg, Germany 2007.

[67] Van Limburg M, Gemert-Pijnen V, Nijland N, Ossebaard HC, Hendrix RMG, Sevdel ER. Why Business Modeling is Crucial in the Development of eHealth Technologies. Journal of Medical Internet Research 2011; 13(4): e124. http://dx.doi.org/10.2196/jmir.1674

[68] Bahga A, Madisetti VK. A Cloud-based Approach for Interoperable Electronic Health Records (EHRs). IEEE Journal of Biomedical and Health Informatics 2013; 17(5): 894-906.

http://dx.doi.org/10.1109/JBHI.2013.2257818

[69] Zahedi F, Song J. Dynamics of Trust Revision: Using Health Infomediaries. Journal Of Management Information Systems 2008; 24(4): 225-248. http://dx.doi.org/10.2753/MIS0742-1222240409

[70] Broderick M, Smaltz DH. E-Health Defined. HIMSS E-Health SIG White Paper 2003. Retrieved October 11, 2009 from www.himss.org/content/files/ehealth_whitepaper.pdf

[71] Morales-Arroyo M, Sharma RS. Deriving Value in Digital Media Networks. International Journal of Computer Science and Security 2009; 3(2): 126-137.

[72] Mettler T, Eurich M. A "design-pattern" -based approach for analyzing e-health business models. Health Policy and Technology 2012; 1(2): 77-85.

http://dx.doi.org/10.1016/j.hlpt.2012.04.005

[73] Blumenthal D. Stimulating the Adoption of Health Information Technology. New England Journal of Medicine 2009; 360(15): 1477-1479. http://dx.doi.org/10.1056/NEJMp0901592

[74] AbuKhousa E, Mohamed N, Al-Jaroodi J. e-Health Cloud: Opportunities and Challenges [Electronic Version] 2012. Future Internet, 621-645. Retrieved 12/09/2014, from http://www.mdpi.com/1999-5903/4/3/621

[75] Sujith E. Cloud Computing in Healthcare. Frost \& Sullivan Market Insight 2008. Retrieved 21/07/2010, from https://www.frost.com/sublib/display-marketinsight.do? id $=135578323$

[76] Lassetter JK. HIEs to Transform. Health Management Technology 2010; 18.

[77] de Brantes F, Emery DW, Overhage JM, Glaser J, Marchibroda J. The potential of HIEs as Infomediaries. Journal of Healthcare Information Management 2007; 21(1): 69-75.

[78] Yip W, Hsiao W. China's health care reform: A tentative assessment. China Economic Review 2009; 20(4): 613-619. http://dx.doi.org/10.1016/j.chieco.2009.08.003

[79] Sunyaev A, Schneider S. Cloud Services Certification. Communications of the ACM 2013; 56(2): 33-36. http://dx.doi.org/10.1145/2408776.2408789

[80] El Sawy O, Pereira F, Fife E. The VISOR Framework: Business Model Definition for New Marketspaces in the Networked Digital Industry. Center for Telecommunications Management, University of Southern California 2008.

[81] Brandenburger AM, Stuart HW. Value-based Business Strategy. Journal of Economics and Management Strategy 1996; 5(1): 5-24.

http://dx.doi.org/10.1111/j.1430-9134.1996.00005.x

[82] Eisenmann TR. Managing Proprietary and Shared Platforms. California Management Review 2008; 50(4): 31-53. http://dx.doi.org/10.2307/41166455

[83] Rappaport A. CFOs and Strategists: Forging a Common Framework. Harvard Business Review 1992; 70: 84-91.

[84] Song J, Zahedi F. Trust in health infomediaries. Decision Support Systems 2007; 43(2): 390-407.

http://dx.doi.org/10.1016/j.dss.2006.11.011
[85] Hagel III J, Rayport JF. The Coming Battle for Customer Information. Harvard Business Review 1997; 75(1): 53-65.

[86] Peters K, Niebling M, Slimmer C, Green T, Webb JM, Schumacher R. Usability Guidance for Improving the User Interface and Adoption of Online Personal Health Records 2009. UserCentric.com. Retrieved September 15, 2009, from http://www.scribd.com/doc/21811231/Usability-Guidance-forImproving-the-User-Interface-and-Adoption-of-OnlinePersonal-Health-Records

[87] Calvillo J, Román I, Roa LM. How technology is empowering patients? A literature review. Health Expectations 2013. http://dx.doi.org/10.1111/hex.12089

[88] Burkhard R. Book Review: Patient-Centred E-Health [Review of the book Patient-Centred E-Health]. International Journal of E-Services and Mobile Applications 2009; 1(3): 79-81.

[89] Powell PT, Laufer R. The promises and constraints of consumer-directed healthcare. Business Horizons 2010; 53(2): 171-182. http://dx.doi.org/10.1016/j.bushor.2009.11.003

[90] Tang PC, Ash JS, Bates DW, Overhage JM, Sands DZ Personal health records: Definitions, benefits, and strategies for overcoming barriers to adoption. Journal of the American Medical Informatics Association 2006; 13(2): 121-6. http://dx.doi.org/10.1197/jamia.M2025

[91] Purcarea O. European Health Telematics Association (EHTEL) Symposium - A decade of dedicated support to eHealth in Europe. Microsoft EMEA Health Blog 2009. Retrieved November 05, 2009 from http://blogs.msdn.com/ms_emea_health_blog/archive/2009/1 0/23/ehtel-a-decade-of-dedicated-support-to-ehealth-ineurope.aspx

[92] Ahern DK. Challenges and Opportunities of eHealth Research. American Journal of Preventive Medicine 2007; 32(5S): S75-S82. http://dx.doi.org/10.1016/j.amepre.2007.01.016

[93] Couch JB. How to use electronic health records to achieve the quadruple aim. JAMA Internal Medicine 2013; 173(3): 250-250.

http://dx.doi.org/10.1001/jamainternmed.2013.1620

[94] Whitten P, Steinfield C, Hellmich S. Ehealth: Market Potential and Business Strategies. Journal of Computer-Mediated Communication 2001; 6(4). http://dx.doi.org/10.1111/j.1083-6101.2001.tb00129.x

[95] Atkinson NL, Saperstein SL, Pleis J. Using the Internet for Health-Related Activities: Findings from a National Probability Sample. Journal of Medical Internet Research 2009; 11(1): e4.

http://dx.doi.org/10.2196/jmir.1035

[96] Kayyali B, Knott D, Van Kuiken S. The 'big data' revolution in healthcare: Accelerating value and innovation [Electronic Version] 2013. Retrieved 10/09/2014, from http://www.mckinsey.com/insights/health_systems_and_servi ces/the_big-data_revolution_in_us_health_care

[97] Payton FC. e-Health Models Leading to Business-toEmployee Commerce in the Human Resources Function. Journal of Organizational Computing and Electronic Commerce 2003; 13(2): 147-161. http://dx.doi.org/10.1207/S15327744JOCE1302 4

[98] DeNardis. E-health standards and interoperability 2014 Retrieved from https://itunews.itu.int/En/2472-E8209; healthstandards-and-interoperability.note.aspx

[99] Jones DK. The Fate of Health Care Reform - What to Expect in 2012. New England Journal of Medicine 2012; 366(4): e7. http://dx.doi.org/10.1056/NEJMp1114858

[100] Goldstein J. Big Challenges Await Health-Records Transition. The Wall Street Journal 2009. Retrieved August 24, 2009 from http://online.wsj.com/article/SB124027664223937475. html 
[101] Miller RH, West C, Brown TM, Sim I, Ganchoff C. The value of electronic health records in solo or small group practices. Health Affairs 2005; 24(5): 1127-1137. http://dx.doi.org/10.1377/hlthaff.24.5.1127

[102] Berthold J. Investing in EHRs pays off in paperless perks. ACP Internist 2008. Retrieved October 29, 2009 from http://www.acpinternist.org/archives/2008/02/ehrs.htm

[103] Brailer DJ. Interoperability: The Key To The Future Health Care System. Health Affairs (Web Exclusive) 2005; W5-19. http://dx.doi.org/10.1377/hlthaff.w5.19

[104] Brandenburger AM, Nalebuff BJ. The Right Game: Use Game Theory to Shape Strategy. Harvard Business Review 1995; 73(4): 57-71.

[105] Brandenburger AM, Stuart HW. Value-based Business Strategy. Journal of Economics and Management Strategy 1996; 5(1): 5-24. http://dx.doi.org/10.1111/j.1430-9134.1996.00005.x
[106] Dixit AK, Nalebuff BJ. The Art of Strategy: A Game Theorist's Guide to Success in Business and Life. New York, NY: W.W. Norton \& Company, Inc. 2008.

[107] Grandori A, Neri M. The fairness properties of interfirm networks. In Grandori A, Ed. Interfirm Networks: Organization and Industrial Competitiveness. London: Routledge 1999; pp. 41-66.

http://dx.doi.org/10.4324/9780203022481.ch0

[108] Grandy C. Through a Glass Darkly: An Economic View of Fairness, Globalization, and States. In Dator JA, Pratt R, Seo Y, Eds. Fairness, Globalization, and Public Institutions: East Asia and Beyond. USA: University of Hawaii Press 2006; pp. 49-60.

[109] Chesbrough H, Rosenbloom RS. The role of the business model in capturing value from innovation: evidence from Xerox Corporation's technology. Industrial and Corporate Change 2002; 11(3): 529-555. http://dx.doi.org/10.1093/icc/11.3.529

Received on 28-10-2015 Accepted on 19-01-2016

Published on 11-02-2016

(C) 2016 Stephanie and Sharma; Licensee Lifescience Global.

This is an open access article licensed under the terms of the Creative Commons Attribution Non-Commercial License (http://creativecommons.org/licenses/by-nc/3.0/) which permits unrestricted, non-commercial use, distribution and reproduction in any medium, provided the work is properly cited. 